\title{
Brief topical and intraluminal use of Carolina rinse solution does not attenuate experimental ischemia and reperfusion injury in rabbit jejunum
}

\author{
[O uso tópico breve e intraluminal da solução de Carolina rinse não atenua a \\ injúria de isquemia e reperfusão experimental no jejuno de coelhos ] \\ L.R.G. Brandstetter ${ }^{l}$, A.C.B.R. Pedroso ${ }^{2}$, H.F. Oliveira ${ }^{I}$, \\ V.M.B.D. Moura $^{l}$, E.G. Araújo \\ ${ }^{1}$ Escola de Veterinária e Zootecnia - Universidade Federal de Goiás - Goiânia, GO \\ ${ }^{2}$ Aluna de pós-graduação- Universidade Federal de Goiás - Goiânia, GO
}

\begin{abstract}
Fifteen New Zealand adult rabbits were randomly allocated into three groups: Sham-operated (group A), Ischemia and Reperfusion (group B) and Carolina Rinse Solution (CRS) (group C). Groups B and C were subjected to one hour of ischemia and two hours of reperfusion. In group $\mathrm{C}$, ten minutes before reperfusion, the bowel lumen was filled with CRS, and the segment immersed in CRS. Necrosis and loss of integrity of the villi were visible in groups B and C. Edema of the submucosa and circular muscle was observed in all groups. Hemorrhage was observed in different layers for groups B and C, but group C showed more severe hemorrhage in different layers during reperfusion. All groups showed polymorphonuclear leukocyte infiltration on the base of the mucosa, submucosa, and longitudinal muscle, in addition to polymorphonuclear leukocytes margination in the mucosal and submucosal vessels. Necrosis of enterocytes, muscles, crypts of Lieberkühn and myenteric plexus was observed in groups B and C during reperfusion. Topical and intraluminal Carolina Rinse Solution did not attenuate the effects of ischemia and reperfusion in the small intestine of rabbits.
\end{abstract}

Keywords: reperfusion injury, small intestine, ischemia

\section{RESUMO}

Quinze coelhos da raça Nova Zelândia foram alocados em três grupos: instrumentado (grupo A), isquemia e reperfusão (grupo B) e solução de Carolina rinse (CRS) (grupo C). Os grupos B e C foram submetidos a uma hora de isquemia e a duas horas de reperfusão. No grupo $C, 10$ minutos antes da reperfusão, $o$ segmento isolado foi imerso e teve seu lúmen preenchido com CRS. Os grupos B e C apresentaram necrose e perda progressiva da integridade das vilosidades. Foi observado edema na submucosa e na camada muscular circular em todos os grupos. Nos grupos B e C, foi observada hemorragia em diferentes camadas, mas, no grupo $C$, a hemorragia foi mais intensa durante a reperfusão. Todos os grupos apresentaram infiltrado de PMN na base da mucosa, na submucosa e na camada muscular longitudinal e marginação de PMN nos vasos da mucosa e da submucosa. Durante a reperfusão, foi observada necrose dos enterócitos, das camadas musculares, das criptas de Lieberkühn e do plexo mioentérico nos grupos B e C. O uso tópico e intraluminal de CRS não atenuou os efeitos da isquemia e da reperfusão no intestino delgado de coelhos.

Palavras-chave: injúria de reperfusão, intestino delgado, isquemia

\section{INTRODUCTION}

Obstruction of blood vessels leads to ischemia and reduction of oxygenation and tissue perfusion
(Moore et al., 1995). Ischemia causes tissue necrosis unless blood flow returns in a timely fashion. However, even if oxygenated blood returns to tissues before cellular death occurs,

Recebido em 28 de fevereiro de 2019

Aceito em 29 de janeiro de 2020

E-mail: lubrands@yahoo.com.br 
reperfusion injury may occur and lead to an inflammatory response (White, 2002). Current tissue-protective treatments against reperfusion injury include the application of extracellular signaling molecules and manipulation of signaling pathways (Guan et al., 2009; Chen et al., 2019; Tackett et al., 2019). Carolina rinse solution (CRS) is a compound of electrolytes similar to plasma designed by North Carolina University, USA. The solution includes allopurinol and glutathione as antioxidants, desferrioxamine as an iron chelator, the calcium channel blocker nicardipine, adenosine for improved microcirculation, and fructose and glucose as adenosine triphosphate substrates (Currin et al., 1990). CRS has attenuated capillary permeability changes and edema formation when experimentally injected into the jejunal artery of ischemic intestinal segments of horses ten minutes before reperfusion (Dabareiner et al., 2005). This study has investigated the effects of topical and intraluminal CRS in a rabbit model of jejunal ischemia and reperfusion (I/R).

\section{MATERIAL AND METHODS}

Fifteen young adult male New Zealand rabbits (Oryctolagus cuniculus), weighing 2-3.5kg, were randomly assigned to three experimental groups of five individuals each: (A) Sham group (Nos. 15) - the animals underwent a surgical procedure, but the mesenteric vessels were not occluded; (B) Ischemia and Reperfusion group (Nos. 6-10) - the mesenteric vessels were occluded for one hour, followed by two hours of reperfusion; and (C) Carolina rinse solution group (Nos. 11-15) - ten minutes prior to reperfusion, the lumen of the isolated segment was filled, but not distended, with $1 \mathrm{ml} / \mathrm{kg}$ body weight of CRS at $37^{\circ} \mathrm{C}$ (Young et al., 2002). In addition, the segment was immersed in $30 \mathrm{ml}$ of CRS in a sterile plastic bag until reperfusion onset.

Anesthesia was induced with 15 to $25 \mathrm{mg} / \mathrm{kg}$ of sodium thiopental (Thipentax®, Cristália Produtos Químicos e Farmacêuticos Ltda., Brazil), intravenously. Maintenance was carried out with continuous infusion of $1.25 \%$ thiopenthal $(60 \mathrm{mg} / \mathrm{kg} /$ hour $)$ during the first hour, and $40 \mathrm{mg} / \mathrm{kg} /$ hour in the following hours. After injecting $5 \mathrm{ml}$ of $2 \%$ lidocaine hydrochloride (Xylestesin® Cristália Produtos Químicos e Farmacêuticos Ltda.) subcutaneously, a sevencentimeter midline incision was performed caudally from the xiphoid process, exposing the bowel. A ten-centimeter segment of distal jejunum was chosen for the study. Both the mesenteric artery and vein were isolated using a $0.2-\mathrm{mm}$ nylon monofilament fishing line and brought together into a $2-\mathrm{cm}$ section of polyvinyl urethral tube No. 4 in order to establish ischemia of the segment. Mosquito hemostatic forceps were used to lock the suture to the tube. Extramural circulation was blocked by means of ligating the intestinal wall extremities with size 2 chromic catgut (Catgut cromado® Ethicon Inc., USA). After one hour of ischemia, the sutures were removed, and the isolated segment remained in reperfusion for two hours. During $I / R$, the segment was carefully replaced into the abdomen, and the skin incision was partially closed using cyanoacrylate fast-acting adhesive (Super 1000®, Three Bond do Brasil, Brazil). At the end of the experiment, the animals were euthanized with a lethal dose of thiopental.

A full-thickness 3-mm biopsy was performed from the antimesenteric border of the isolated segment using Metzenbaum scissors. Specimens were harvested at five different time points during surgery: T0: Before vascular clamping; T5i: 5 minutes after ischemia onset; T5r: 5 minutes after reperfusion onset; T60r: 60 minutes after reperfusion onset, and T120r: 120 minutes after reperfusion onset. The samples of Group A were harvested at similar times. The defects were sutured using size 3-0 nylon monofilament (Moura and Draschi Ltda, Brazil). Samples were fixed in buffered $10 \%$ formalin for 24 hours and kept in $70 \%$ ethyl alcohol solution until dehydrated and embedded in paraffin. Fivemicrometer thick sections were mounted onto glass slides, stained with hematoxylin and eosin (HE) and examined through a light microscopy (Leica $^{\mathrm{TM}}$ DM 4000B, Germany) with 200, 400 and 1000x magnification.

The jejunal sites assessed for histological evaluation were the villi structure, enterocytes, lamina propria, crypts of Lieberkühn, base of mucosa (where crypts are located), submucosa, circular muscle, myenteric plexus and longitudinal muscle. Microscopic variables such as edema, polymorphonuclear leukocytes (PMN) infiltration and margination, hemorrhage and necrosis were considered for this study. 
The criteria used to score the intensity and distribution of histological changes consisted of a score system where 0 stood for no changes, 1 for mild intensity or focal distribution, 2 for moderate intensity or multifocal distribution, and 3 for strong intensity or diffuse distribution. Data were analyzed by the Kruskal Wallis test, followed by the Student Newman-Keuls multiple-comparison test when necessary. Differences were considered significant at the $95 \%$ confidence level $(\mathrm{P}<0.05)$. The study was approved by the Research Ethics Committee (CoEP) of Universidade Federal de Goiás (protocol number 011/1).

\section{RESULTS}

Animals placed in groups $\mathrm{B}$ and $\mathrm{C}$ showed discoloration of the isolated segment, which became more intense over time. During reperfusion, segments became hyperemic and presented a substantial increase in wall thickness. Jejunal veins grew ingurgitated and dark red during ischemia. Upon harvesting the intestinal sample, little hemorrhage was observed in groups $\mathrm{A}$ and $\mathrm{B}$ during reperfusion. However, in group $\mathrm{C}$ it was observed that hemorrhage was difficult to be controlled with regular suture, requiring additional suturing.

Considering the histological findings, integrity of the villi was preserved in group A (Figure 1A). Detachment of enterocytes and lamina propria disintegration, after the beginning of reperfusion (Figure 1B), were observed in groups B and C. Diffused necrosis of enterocytes was observed in groups $\mathrm{B}$ and $\mathrm{C}$ within five minutes of reperfusion and, after two hours of reperfusion, both groups showed similar shortening of the villus.

Edema was observed predominantly in the submucosa and circular muscle layer in all groups and at all times. Although in groups $B$ and $C$ this finding was apparent in the myenteric plexus, less intense edema also appeared in group A after one hour of reperfusion. The longitudinal muscle layer showed significant progressive edema that became intensive after two hours of reperfusion in groups $\mathrm{B}$ and $\mathrm{C}$, with no difference between groups.

Animals allocated to groups B and C showed hemorrhage in lamina propria, base of mucosa (Figure 1C), submucosa, circular, and longitudinal muscle layers (Figure 1D). Hemorrhage started soon after reperfusion onset in lamina propria. For all other layers, hemorrhage was more evident and progressive in group $\mathrm{C}$ during reperfusion compared to group B.

PMN margination became evident during reperfusion at the base of mucosal vessels, as well as the submucosa in all animals. In group B, five minutes after reperfusion commenced, the base of the mucosa showed more intense and diffused margination. Animals from groups $\mathrm{B}$ and $\mathrm{C}$ presented significantly more intense PMN margination in the submucosa, at T5r sample, when compared to group A, with no difference between groups $\mathrm{B}$ and $\mathrm{C}$.

PMN infiltration was present in all groups and all times at the base of the mucosa, with no difference between groups. Mild focal PMN infiltration was observed in the longitudinal muscle layer only at T120r sample, in all groups. Circular muscle presented mild PMN infiltration in groups B and $\mathrm{C}$ after 60 minutes of reperfusion, and in all groups after two hours of reperfusion, but there was no significant difference between groups.

After reperfusion onset, the animals from both groups subjected to $I / R$ showed progressive necrosis of enterocytes, crypts of Lieberkühn, myenteric plexus, circular and longitudinal muscles (Figure 2). 


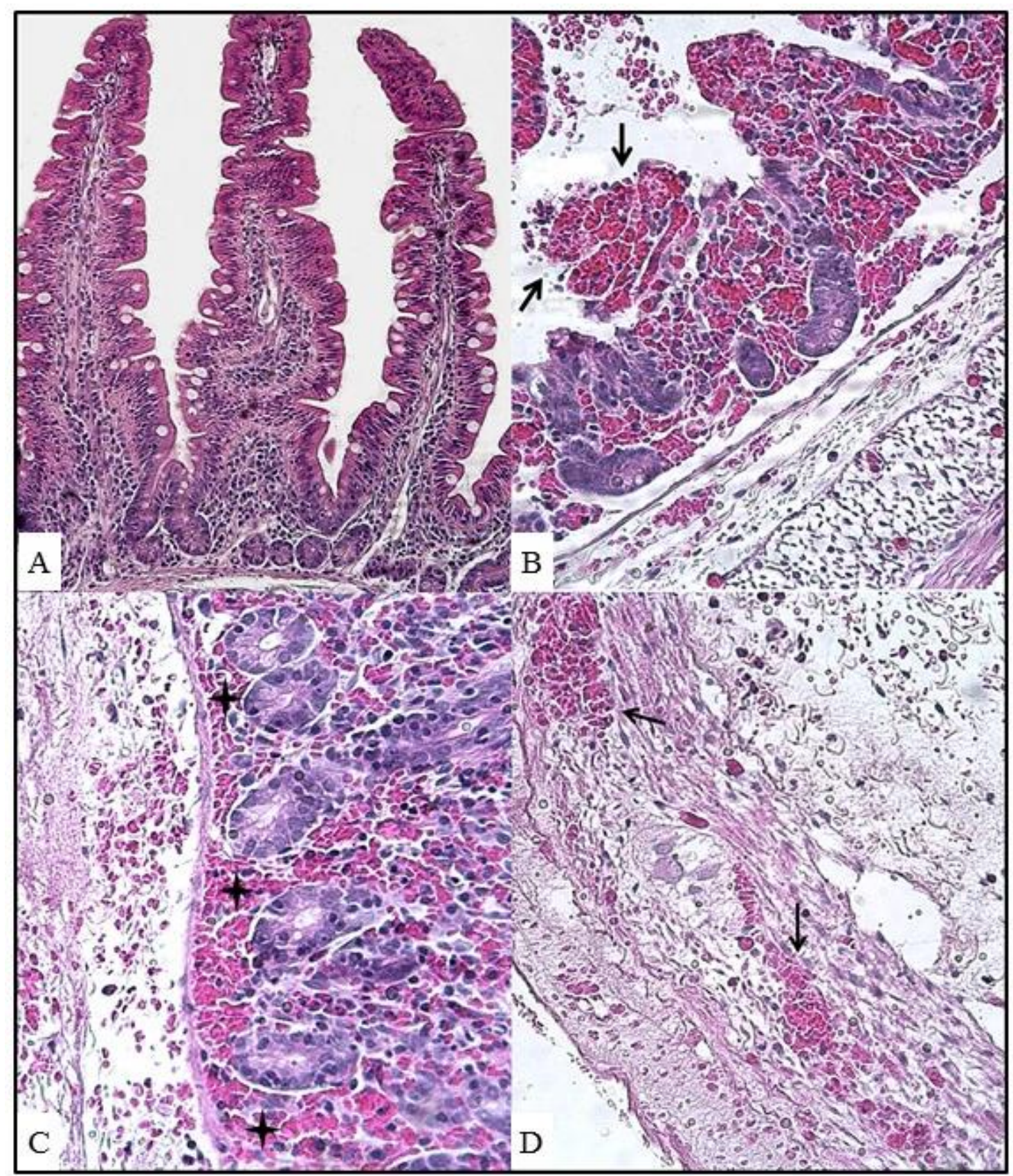

Figure 1. Photomicrographies of rabbit jejunums. A. Subject No. 2, T120r sample. Integrity of the villi preserved. B. Subject No. 6, T60r sample. Enterocytes detachment and lamina propria disintegration (arrows). C. Subject No. 11, T120r sample. Intense hemorrhage at the base of the mucosa (stars). D. Subject No. 11, T120r sample. Hemorrhage within muscle layers (arrows). HE. 


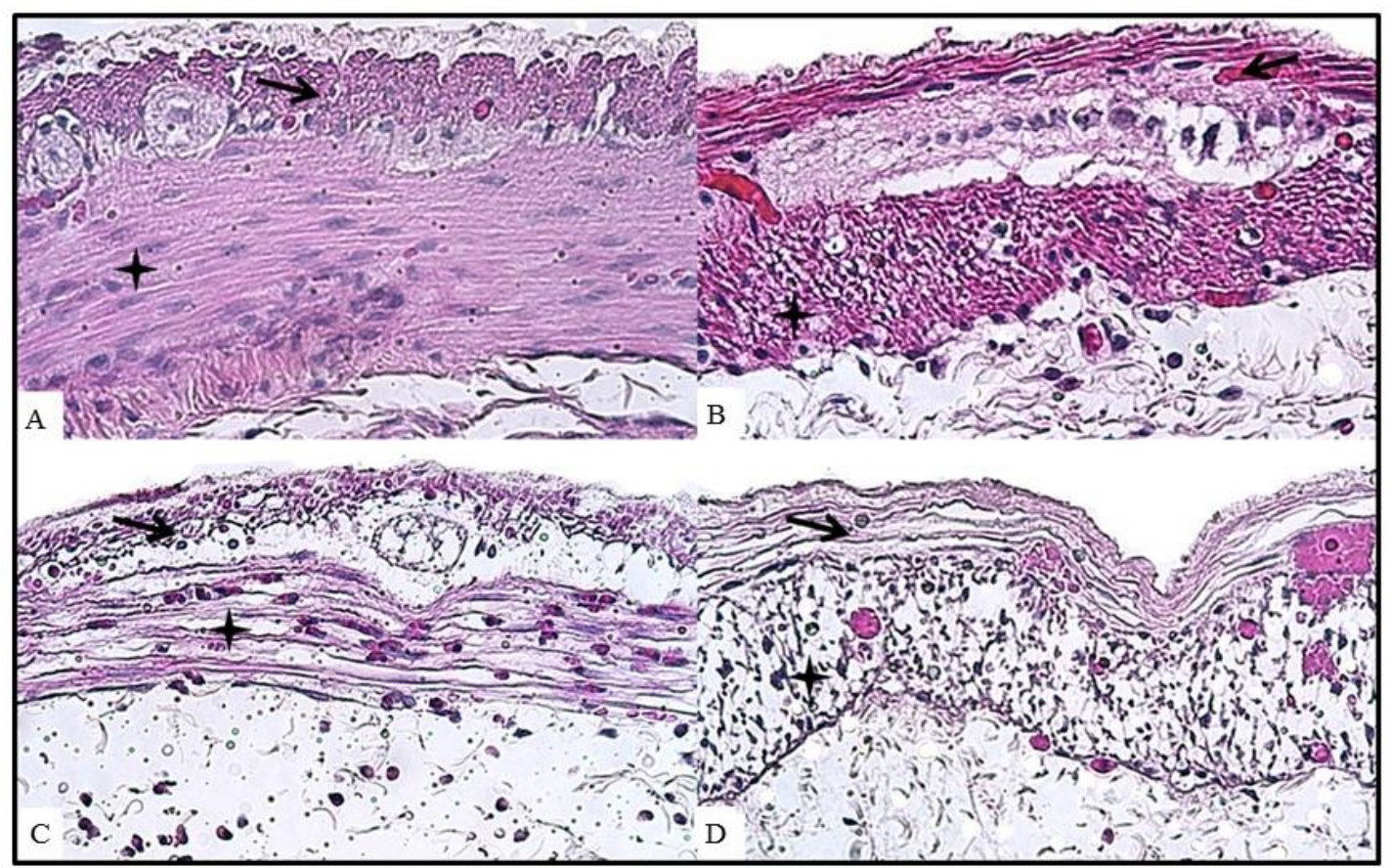

Figure 2. Photomicrographies of rabbit jejunums A. Subject No. 4, T5r sample. Normal aspect of circular (stars) and longitudinal (arrows) muscle layers. B. Subject No. 6, T5r sample. Circular (stars) and longitudinal (arrows) muscle layers showing multifocal areas of necrosis. C. Subject No. 10, T120r sample. Circular (stars) and longitudinal (arrows) muscle layers with diffused necrosis. D. Subject No. 14, T120r sample. Circular (stars) and longitudinal (arrows) muscle layers with diffused necrosis. HE.

\section{DISCUSSION}

Previous studies have standardized the time of intestinal ischemia in rabbits ranging from one hour (Gomes et al., 2010) to two hours (Oliveira et al., 2018), in order to prevent irreversible tissue lesions. In this study, integrity of the villi was preserved in group A (Figure 1A). Detachment of enterocytes, lamina propria disintegration, and the presence of necrotic material were observed in groups B and C (Figure 1B), as found in previous studies (Gomes et al., 2010; Gordeeva et al., 2015). After two hours of reperfusion (T120r), groups $\mathrm{B}$ and $\mathrm{C}$ showed similar shortening of the villus. Interestingly, such changes were not observed in horses after one hour of small intestinal ischemia (Dabareiner et al., 1995). Additionally, a human experimental model showed that 30 minutes of jejunal ischemia only moderately affects intestinal barrier function (Schellekens et al., 2017).

In order to assess the ischemic injury, a six-point scale has been described, where grade 0 represents the absence of changes and grade $I$ is characterized by the development of a subepithelial space and slight epithelial lifting at the villus tip. The changes progress to loss of the epithelial layer in sheets, starting at the villus tip, until complete loss of the villus architecture, with severe mucosal hemorrhage and loss of the lamina propria (grade V) (Chiu et al., 1970). According to this scale, in groups $\mathrm{B}$ and $\mathrm{C}$ mucosal damage reached grade IV (characterized by denuded villi with exposed lamina propria and dilated capillaries) or $\mathrm{V}$ after reperfusion started, but there was no significant difference between groups.

It has been shown that enterocytes located at the tips of the villi are more sensitive to the effect of ischemia (Kong et al., 1998). However, a study in a rat model demonstrated that the sensitivity of an enterocyte is dependent on its state of differentiation (Hinnebusch et al., 2002). In our study, the villi were already severely compromised after one hour of ischemia, and enterocytes from both the tip and base of the villi showed diffused necrosis. 
Edema of the submucosa and circular muscle layer could be a result of tissue handling (Dabareiner et al., 1995). When injured or activated, endothelial cells become turgid, their morphology changes, and capillary permeability increases. Muscle layer edema is a common finding in experimental intestinal I/R due to early changes in capillary permeability during ischemia (Haglund, 1994).

Modifications in capillary permeability lead to extravasation of erythrocytes. Although intestinal manipulation in group A has resulted in edema, changes in capillary permeability were probably not severe enough to allow erythrocytes to cross the endothelial barrier, causing hemorrhage. However, in ten rabbits (groups B and C) hemorrhage was observed in the lamina propria, base of the mucosa (Figure 1C), submucosa, and circular and longitudinal muscle layers (Figure 1D). Hemorrhage developed shortly after reperfusion in the lamina propria in groups B and C. For all other layers, except the submucosa, after reperfusion inception, hemorrhage was more evident in group $\mathrm{C}$ compared to group $\mathrm{B}$. Moreover, within two hours of reperfusion, the submucosa showed significant hemorrhage in group C compared to group B. Also, the discreet hemorrhage that sprouted from the incision while harvesting samples in groups A and B during reperfusion was easily controlled by suturing the defect. However, hemorrhage was difficult to control in group $\mathrm{C}$ and required additional suturing.

The effects of one of the CRS compounds could explain the hemorrhage scores and increased incisional bleeding observed in group $\mathrm{C}$. The purine nucleoside adenosine, a potent vasodilator in almost all vascular beds, occupies a unique position in the regulation of microcirculation, inflammatory response, and neurogenic activity in the gut. Adenosine participates in the control of vascular tone (Rubino et al., 1995) and is a potent inhibitor of platelet aggregation and inflammatory response (Reiss et al., 2019). In addition, adenosine infusion increases blood flow to the gastrointestinal tract (Pennanen et al., 1994), and may have neuroprotective effects (Seydyousefi et al., 2019). Therefore, changes in capillary permeability induced by $\mathrm{I} / \mathrm{R}$ combined with vasodilation and platelet aggregation inhibition might have contributed to increase hemorrhage.
Intestinal $\mathrm{I} / \mathrm{R}$ injury has been shown to be associated with intense inflammatory response and the accumulation of neutrophils during the reperfusion period (Horton \& Walker, 1993). Infiltration of PMN at the base of the mucosa of experimental models was previously described in control groups (Sullins et al., 1985). Moreover, laparotomy and intestinal manipulation can cause an inflammatory response in the intestine, including leukocyte recruitment, depending on the intensity of manipulation (Kalff et al., 1998). Thus, every segment exteriorization for sample harvesting probably resulted in an insult, despite the careful manipulation of the intestine. Allopurinol is supposed to prevent increases in microvascular permeability and neutrophil infiltration (Grisham et al., 1986). Since PMN infiltration and margination in the submucosa was similar in groups B and C, allopurinol did not produce such effect. However, the beneficial effects of allopurinol attenuating neutrophil infiltration have been observed with intravenous injection prior to ischemia (Sapalidis et al., 2013).

After reperfusion onset, animals from groups B and $\mathrm{C}$ showed progressive necrosis of enterocytes, crypts of Lieberkühn, myenteric plexus, circular and longitudinal muscles (Figure 2). There are not many reports about the changes observed in muscle layers of the small intestine after ischemia and reperfusion. Moreover, some reports show conflicting results. One study did not show any significant changes other than infiltration of inflammatory cells in muscle layers following one hour of ischemia and up to ten weeks of reperfusion of a rat's small intestine (Lindestrom and Ekblad, 2004). Nevertheless, in the small intestine of guinea pigs, about $10 \%$ of smooth muscle cells show apoptosis at six and 12 hours of reperfusion, following one hour of ischemia. Degenerative changes are likely in enteric neurons, and some neurons are lost following I/R injury (Mei et al., 2009).

As an earlier study showed, the combined use of topical and intraluminal CRS was effective in reducing expected neutrophil migration in equine jejunum and was considered an applicable treatment to prevent immediate inflammatory changes during reperfusion after low flow ischemia (Young et al., 2002). However, in that study, the intestinal segment was immersed in CRS prior to reperfusion and remained immerse for 60 minutes. In our experiment, manipulation 
and maintenance of such a small segment was difficult to achieve without overflowing the content out of the plastic bag. Additionally, CRS was briefly and topically used in an attempt to mimic clinical conditions, such as those related to acute strangulating obstruction of the small intestine, when preventive treatment can be frustrating and unfeasible. In those cases, there can be severe blood flow impairment, leading to urgent need for surgery, whereas prolonged immersion and surgical time could lead to severe complications.

\section{CONCLUSION}

Topical and intraluminal Carolina rinse solution does not prevent damage caused by small intestinal ischemia and reperfusion. In this study, the brief use of CRS did not attenuate the deleterious effects of experimental ischemia and reperfusion in the small intestine of rabbits. The data suggest that the beneficial results previously reported are probably attributed to the early addition of CRS or the prolonged immersion time and reinforce the reason for the drastic fatality figures related to the clinical conditions of acute abdomen involving intestinal blood flow interruption.

\section{REFERENCES}

CHEN, S.F.; LI, X.; WANG, Y. et al. Ginsenoside $\mathrm{Rb} 1$ attenuates intestinal ischemia/reperfusioninduced inflammation and oxidative stress via activation of the PI3K/Akt/Nrf2 signaling pathway. Mol. Med. Rep., v.19, p.3633-3641, 2019.

CHIU, C.J.; McARDIE, A.H.; BROWN, R. et al. Intestinal mucosal lesion in low-flow states. I. A morphological, hemodynamic, and metabolic reappraisal. Arch. Surg.; v.101, p.478-83, 1970.

CURRIN, R.T.; TOOLE, J.G.; THURMAN, R.G.; LEMASTERS, J.J. Evidence that Carolina rinse solution protects sinusoidal endothelial cells against reperfusion injury after cold ischemic storage of rat liver. Transplantation, v.50, p.10761078, 1990.
DABAREINER, R. M.; WHITE, N.A.; SNYDER, J.R. et al. Effects of Carolina rinse solution, dimethyl sulfoxide, and the 21aminosteroid, U-74389G, on microvascular permeability and morphology of the equine jejunum after low-flow ischemia and reperfusion. Am. J. Vet. Res., v.66, p.525-536, 2005.

DABAREINER, R.M.; SNYDER, J.R.; WHITE, N.A. et al. Microvascular permeability and endothelial cell morphology associated with lowflow ischemia/reperfusion injury in the equine jejunum. Am. J. Vet. Res., v.56, p.639-648, 1995.

GOMES, O.M.; BRASILEIRO FILHO, G.; PORTO, L.A.B. et al. Ischemia-reperfusion histopathology alterations of the rabbit intestinal wall with and without exclusion of the collateral mesenteric circulation supply. Acta Cir. Bras., v.25, p.318-21, 2010.

GORDEEVA, A.E.; TEMNOV, A.A.; CHARNAGALOV, A.A. et al. Protective effect of peroxiredoxin 6 in ischemia/reperfusioninduced damage of small intestine. Dig Dis Sci., v.60, p.3610-3019, 2015.

GRISHAM, M.B.; HERNANDEZ, L.A.; GRANGER, D.N. Xanthine oxidase and neutrophil infiltration in intestinal ischemia. Am. J. Physiol., v.251, p.G567-G574, 1986.

GUAN, Y.; WORRELL, R.T.; PRITTS, T.A.; MONTROSE, M.H. Intestinal ischemiareperfusion injury: reversible and irreversible damage imaged in vivo. Am. J. Physiol. Gastrointest. Liver Physiol, v.297, p.G187-G196, 2009.

HAGLUND, U. Gut ischaemia. Gut, v.35, Suppl, p.S73-S76, 1994.

HINNEBUSCH, B.F.; MA, Q.; HENDERSON, J.W. et al. Enterocyte response to ischemia is dependent on differentiation state. J. Gastrointest. Surg., v.6, p.403-409, 2002.

HORTON, J.W.; WALKER, P.B. Oxygen radicals, lipid peroxidation, and permeability changes after intestinal ischemia and reperfusion. J. Appl. Physiol., v.74, p.1515-1520, 1993.

KALFF, J.C.; SCHRAUT, W.H.; SIMMONS, R.L.; BAUER, A.J. Surgical manipulation of the gut elicits an intestinal muscularis inflammatory response resulting in postsurgical ileus. Ann. Surg., v.228, p.652-63, 1998. 
KONG, S.E.; LEWIS, R.; KATHRYN, A. et al. Ischaemia-reperfusion injury to the intestine. Aust. N.Z. J. Surg., v.68, p.554-561, 1998.

LINDESTROM, L.; KBLAD, E. Structural and neuronal changes in rat ileum after ischemia with reperfusion. Diges. Dis. Sci., v.49, p.1212-1222, 2004.

MEI, F.; GUO, S.; HE, Y.T. et al. Apoptosis of interstitial cells of Cajal, smooth muscle cells, and enteric neurons induced by intestinal ischemia and reperfusion injury in adult guinea pigs. Virchows Arch., v.454, p.401-409, 2009.

MOORE, R.M.; MUIR, W.W.; GRANGER, D.N. Mechanisms of gastrointestinal ischemiareperfusion injury and potential therapeutic interventions: a review and its implications in the horse. J. Vet. Intern. Med., v.9, p.115-32, 1995.

OLIVEIRA, A.P.L.; RANGEL, J.P.P.; RIODADES, L.F.S. et al. Establishment of an experimental model of small intestinal ischemia and reperfusion injuries in New Zealand rabbits. Pesqui. Vet. Bras., v.38, p. 1664-1674, 2018.

PENNANEN, M.F.; BASS, B.L.; DZIKI, A.J.; HARMON, J.W. Adenosine: differential effect on blood flow to subregions of the upper gastrointestinal tract. J. Surg. Res., v.56, p.461$465,1994$.

REISS, A.B.; GROSSFELD, D.; KASSELMAN L.J. et al. Adenosine and the cardiovascular system. Am. J. Cardiovasc. Drugs, v.19, p.449464, 2019.

RUBINO, A.; RALEVIC, V.; BURNSTOCK, G. Contribution of P1-(A2b subtype) and P2purinoceptors to the control of vascular tone in the rat isolated mesenteric arterial bed. Br. J. Pharmacol., v.115, p.648-652, 1995.
SAPALIDIS， K.; PAPAVRAMIDIS， T.S.; GIALAMAS, E. et al. The role of allopurinol's timing in the ischemia reperfusion injury of small intestine. J. Emerg. Trauma Shock, v.6, p.203208, 2013.

SCHELLEKENS，D.H.; HUNDSCHEID， I.H.; LEENARTS, C.A. et al. Human small intestine is capable of restoring barrier function after short ischemic periods. World J. Gastroenterol., v.23, p.8452-8464, 2017.

SEYDYOUSEFI, M.; MOGHANLOU, A.E.; METZ, G.A.S. et al. Exogenous adenosine facilitates neuroprotection and functional recovery following cerebral ischemia in rats. Brain Res. Bull., v.153, p.250-256, 2019.

SULLINS, K.E.; STASHAK, T.S.; MERO, K.N. Pathologic changes associated with induced small intestinal strangulation obstruction and nonstrangulating infarction in horses. Am. J. Vet. Res., v.46, p.913-916, 1985.

TACKETT, J.J.; GANDOTRA, N.; BAMDAD, M.C. et al. Potentiation of serotonin signaling protects against intestinal ischemia and reperfusion injury in mice. Neurogastroenterol. Motil., v.31, p.e13498, 2019.

WHITE, N.A. Intestinal injury in the horse. In: SMITH, B.P. (Eds.). Large animal internal medicine. 3.ed. [Los Angeles]: Mosby, 2002. p.624-633.

YOUNG, B.L.; WHITE, N.A.; DONALDSON, L.L.; DABAREINER, R. M. Treatment of ischaemic jejunum with topical and intraluminal Carolina Rinse. Equine Vet. J.,v.34, p.469-74, 2002. 